\title{
ANALYSIS OF CARBON DIOXIDE EMISSION FROM LAWN ECOSYSTEM WITH CONTRASTING SOIL PROFILES
}

\author{
Bhoobun Bhavish, V.I. Vasenev, \\ R.A. Hajiaghayeva \\ RUDN Universuty \\ Miklukho-Maklay str., 8/9, Moscow, Russia, 117198
}

\begin{abstract}
Land-use change is among the main factors contributing to climate change. Urbanization is a landuse change pathway, conjugate with a rapid growth of urban territory and irreversible change of soil features and functioning. Greenhouse gases' emissions (primarily $\mathrm{CO}_{2}$ emission) and carbon sequestration are among important soil functions. Ecological risks of increased $\mathrm{CO}_{2}$ emissions in urban soils are determined by different factors of anthropogenic impact. This paper aims to analyze the impact of different soil constructions on $\mathrm{CO}_{2}$ emissions from urban lawns. The research plot is situated in northern Administrative district of Moscow (NAD) and included urban soil constructions with organic layers of different genesis (turf, sand-turf mixtures and soils-sand mixtures) and of different depth $(5,10$ and $20 \mathrm{~cm})$. As a result an average $\mathrm{CO}_{2}$ emission from turf ( $20 \mathrm{~cm}$ dept of organic layer) was $22 \mathrm{~g} / \mathrm{m}^{2}$ day, whereas the sand-turf mixture ( $10 \mathrm{~cm}$ of the organic layer) emitted 16.15 and peat soil ( $5 \mathrm{~cm}$ of organic layer) $-19.23 \mathrm{~g} / \mathrm{m}^{2}$ day respectively. Therefore, was observed dependence of $\mathrm{CO}_{2}$ emissions on genesis and depth of soil organic layers. Also was revealed dependence of $\mathrm{CO}_{2}$ emissions on climate conditions for nine-months of observations.
\end{abstract}

Key words: $\mathrm{CO}_{2}$ emission, urbanization, urban land use, greenhouse gas, soil respiration

\section{INTRODUCTION}

Soil is a key natural resource with major ecological functions [1-3]. Current realities include continuous expansion of urban areas. Urban soils have recently attracted the attention of researchers $[9 ; 5 ; 4 ; 8]$. Artificial urban soils with prevalence of turf grass in their vegetation, account for a considerable part of the urban soils. This particular soil type is becoming the main object when studying the soils of urban ecosystems $[28 ; 7]$. However, the functioning of urban soils is evidently subject to drastic changes owing to human impact, as any other component of the urban ecosystems $[6 ; 10]$.

It is estimated that artificial changes in land-use have, until now, produced a cumulative global loss of carbon from the land of about 200 thousand million tones. Widespread deforestation has been the main source of this loss, estimated to be responsible for nearly 90 percent of losses since the mid-nineteenth century. Losses primarily occur due to the relatively long-term carbon sinks of forests being replaced by agricultural land. Land-use change is driven by a host of social, political and economic factors around the world. Increased awareness of the most sensitive way to manage land and the better agricultural practice, combined with political agreement on food trade and avoidance of deforestation, are required if land-use change is not to continue being a net global source of carbon to the atmosphere in years to come. Indeed, having degraded large areas of the terrestrial carbon sink, sensitive land-use change may in fact provide a sink for atmospheric greenhouse gases in the future. 
Carbon dioxide is released from the soil through soil respiration, which includes three biological processes, namely microbial respiration, root respiration and faunal respiration primarily at the soil surface or within a thin upper layer where the bulk of plant residue is concentrated [18], and one non-biological process, i.e. chemical oxidation which could be pronounced at higher temperatures [19]. Soil micro-flora contributes $99 \%$ of the $\mathrm{CO}_{2}$ arising as a result of decomposition of organic matter [22], while the contribution of soil fauna is much less [20]. Root respiration, however, contributes $50 \%$ of the total soil respiration [21].

Temperature has a marked effect on $\mathrm{CO}_{2}$ evolution from the soil. Edward found a strong relationship between $\mathrm{CO}_{2}$ evolution and mean daily litter temperature [23]. Wiant observed no $\mathrm{CO}_{2}$ evolution at $10^{\circ} \mathrm{C}$ followed by a logarithmic increase in $\mathrm{CO}_{2}$ evolution between 20 and $40{ }^{\circ} \mathrm{C}$; above $50^{\circ} \mathrm{C}$, it declined rapidly [24]. At higher temperatures partial inhibition of microbial respiration occurs, which is attributed to inactivation of biological oxidation systems. But Bunt and Rovira [19] found increased $\mathrm{CO}_{2}$ evolution with a rise in temperature above $50{ }^{\circ} \mathrm{C}$ as well. Maximum $\mathrm{CO}_{2}$ evolution rate was noted in mid-July (190 $\mathrm{kg} \mathrm{CO}_{2}$ ha-1d-1), which is attributed to the increasing role of root activity and organic matter decomposition with the increase in temperature. Increase in $\mathrm{CO}_{2}$ emission with temperature is a matter of concern, as the possible global warming would increase $\mathrm{CO}_{2}$ evolution from the soil that would accelerate the depletion of soil carbon and soil fertility [25].

Soil moisture affects soil respiration and hence $\mathrm{CO}_{2}$ evolution [26]. In general, increasing soil moisture would increase $\mathrm{CO}_{2}$ evolution up to an optimum level, above which it would reduce $\mathrm{CO}_{2}$ evolution. Periodic drying and wetting of soil has a pronounced influence on $\mathrm{CO}_{2}$ evolution. When the soil is moisten the activity of the microbes, which were in a latent state in the dry soil, increases accompanied by releasing of air trapped in the soil pore contributing to an increase in $\mathrm{CO}_{2}$ evolution [27].

The research work aimed to analyze the carbon dioxide emissions from the artificial soil construction under urban lawns. To achieve the aims the following research steps were taken:

1) to analyze the emissions of carbon dioxide for the contrasting soil structures;

2) to analyze the dynamics of the flow of carbon dioxide, temperature and moisture of contrasting soil structures;

3) to assess the impact of the genesis and depth of organic substrates on carbon dioxide flows and temperature of urban lawns.

\section{MATERIALS AND METHODS}

The research field is situated in Moscow Timiryazev Agricultural Academy. On the field there are 28 different containers with different substrates of different depth. All the containers have the size of $100 \mathrm{~cm} \times 100 \mathrm{~cm} \times 50 \mathrm{~cm}$ and were made from plastics (Fig. 1A). The containers contained different soil constructions were divided into groups according to the type of the organic substrate and the depth of the organic layer. The organic layer is the first layer from the top, containing the substrate used for the experiment; the second layer is sand and the third is the native sod-podzolic soil (B horizon) (Fig. 1B). 


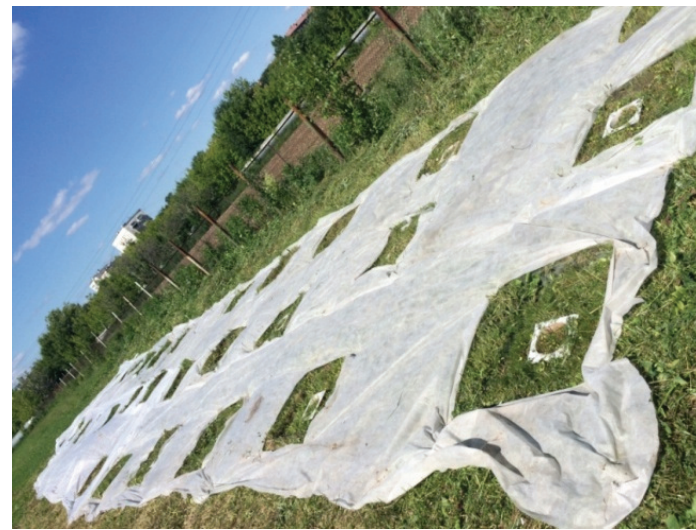

A

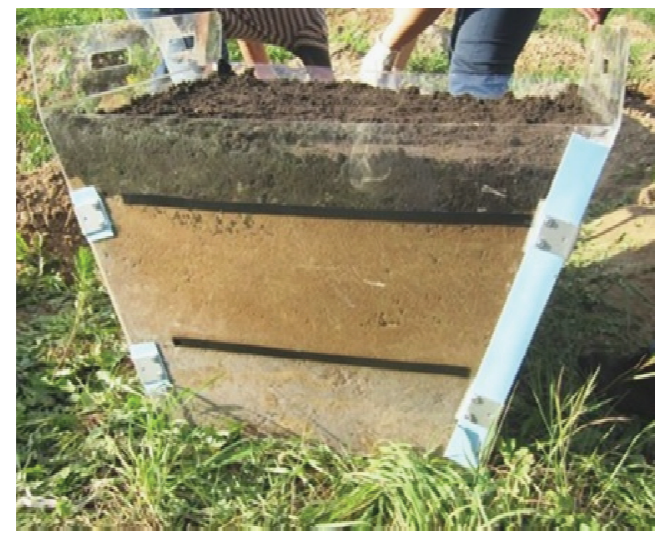

$\mathrm{B}$

Figure 1. The research field of Moscow Timiryazev Agricultural Academy (A) and an artificial soil construction with three different layers (B)

The following substrates have been chosen for the experiment: control (C), turf-sand mixture (Ts), turf (T) and peat-soil mixture (Pso) with two different depths $(5 \mathrm{~cm}$ and $20 \mathrm{~cm}$ ). In order to measure the $\mathrm{CO}_{2}$ flux, moisture, soil temperature and air temperature, an infrared gas analyzer (IRGA) Li-820, chamber, soil thermometer (HI98501) and soil moisture meter (HH2) were used. The observations of $\mathrm{CO}_{2}$ emissions were held from March to September 2014. The dynamics of total soil respiration ( 9 times for the whole period) was analyzed for each container. The IRGA chambers (diameter $20 \mathrm{~cm}$, height $15 \mathrm{~cm}$ ) were installed on the bases (diameter $20 \mathrm{~cm}$, depth $4 \mathrm{~cm}$ ) on top of soil construction and hermetically fixed. The chambers were connected with the IRGA with flows of incoming and outgoing air. With the integrated air pump an air sample from chamber was pumped into the IRGA, whereby the device registered the rise of $\mathrm{CO}_{2}$ concentration in the chamber at a frequency of $1 \mathrm{~Hz}$. Based on the data obtained from the concentration of growth, taking into account the temperature and pressure of the air inside the chamber, $\mathrm{CO}_{2}$ flux $\left(\mathrm{g} / \mathrm{m}^{2}\right.$ day) was calculated using ideal gas equations.

\section{RESULTS AND DISCUSSION}

The dynamics of $\mathrm{CO}_{2}$ fluxes between turf-sand $(20 \mathrm{~cm}$ depths $)$, turf-sand $(5 \mathrm{~cm})$ and control (turf-sand; $10 \mathrm{~cm}$ ) were compared to understand the variation of the $\mathrm{CO}_{2}$ fluxes from different soil constructions. The results show that in July 2014 the carbon dioxide efflux from the turf-sand $(20 \mathrm{~cm})$ was $12.91\left(\mathrm{~g} / \mathrm{m}^{2}\right.$ day) and for the control construction it was $6.3\left(\mathrm{~g} / \mathrm{m}^{2}\right.$ day), whereas $\mathrm{CO}_{2}$ efflux from turf-sand $(5 \mathrm{~cm})$ was $6.95\left(\mathrm{~g} / \mathrm{m}^{2}\right.$ day). The $\mathrm{CO}_{2}$ flux from turf-sand $(20 \mathrm{~cm})$ was 7.43 more than from turfsand $(5 \mathrm{~cm})$ and 0.82 more than from control. Therefore, it can be claimed that $\mathrm{CO}_{2}$ efflux was higher from the urban soil constructions, containing more organic carbon (Fig. 2). Analysis of the peat-soil samples with different depths gave the following results: an average $\mathrm{CO}_{2}$ efflux from the control site was $24.64\left(\mathrm{~g} / \mathrm{m}^{2}\right.$ day), whereas the amount of $\mathrm{CO}_{2}$ emitted from the peat soil $(5 \mathrm{~cm})$ was $20.68 \mathrm{~g} / \mathrm{m}^{2}$ day. In average the $20 \mathrm{~cm}$ peat soil mixture emitted 15 and $30 \%$ more $\mathrm{CO}_{2}$ that the $5 \mathrm{~cm}$ peat soils and the control soil mixture respectively (Fig. 3). This outcome confirms a positives correlation between the amount of emitted $\mathrm{CO}_{2}$ and carbon contents in substrate. 


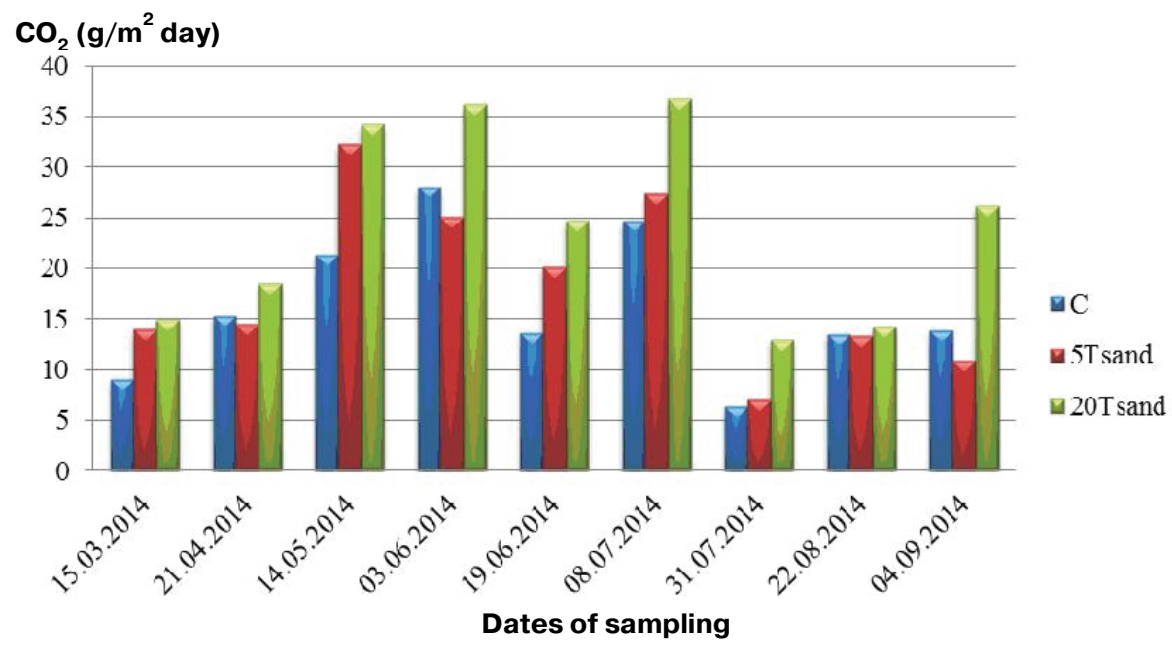

Figure 2. $\mathrm{CO}_{2}$ fluxes from control (C), $5 \mathrm{~cm}$ turf-sand (5Tsand) and $20 \mathrm{~cm}$ turf-sand (20 Tsand) for the period March $15-$ September 42014

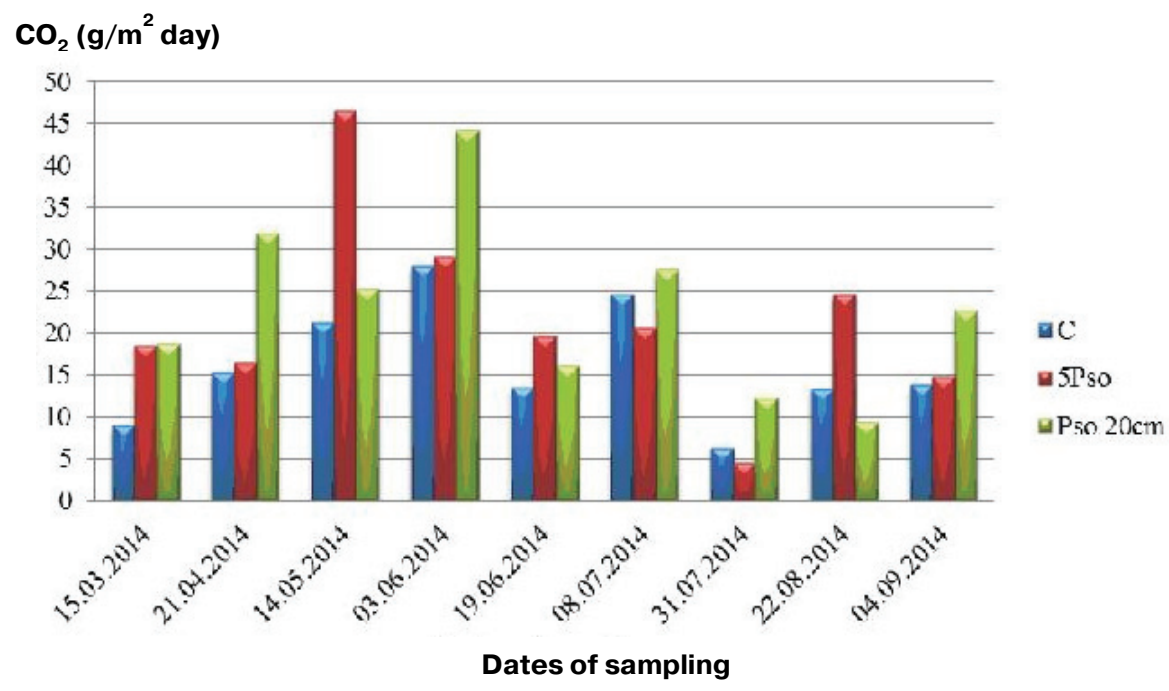

Figure 3. $\mathrm{CO}_{2}$ fluxes from control (C), $5 \mathrm{~cm}$ peat-soil (5Pso) and $20 \mathrm{~cm}$ peat-soil (20 Pso) for the period March $15-$

September 42014

Comparisons of the dynamics of $\mathrm{CO}_{2}$ fluxes between turf-soil $(20 \mathrm{~cm})$, turf-soil $(5 \mathrm{~cm})$ and control (turf-sand; $10 \mathrm{~cm}$ ) for one day - 14th of July 2014 - resulted in following: the highest $\mathrm{CO}_{2}$ emission was found for the turf-soil $(5 \mathrm{~cm})$ and was 53.95 $\left(\mathrm{g} / \mathrm{m}^{2}\right.$ day), whereas and a $20 \mathrm{~cm}$ turf-soil and control emitted just half of this value -25 and $21\left(\mathrm{~g} / \mathrm{m}^{2}\right.$ day) respectively. In average for the season $20 \mathrm{~cm}$ turf-soil mixture emitted more $\mathrm{CO}_{2}$ than other, whereas $\mathrm{CO}_{2}$ emission from the control site was the lowest (Fig. 4).

In order to analyze the seasonal dynamics of $\mathrm{CO}_{2}$ fluxes the three soil constructions with the same depth $(5 \mathrm{~cm})$ were monitored along the nine month of the experiment. The lowest emission was obtained for the 31th of July 2014, whereas the highest amount was monitored on 14th of May 2014 (Fig. 5). 


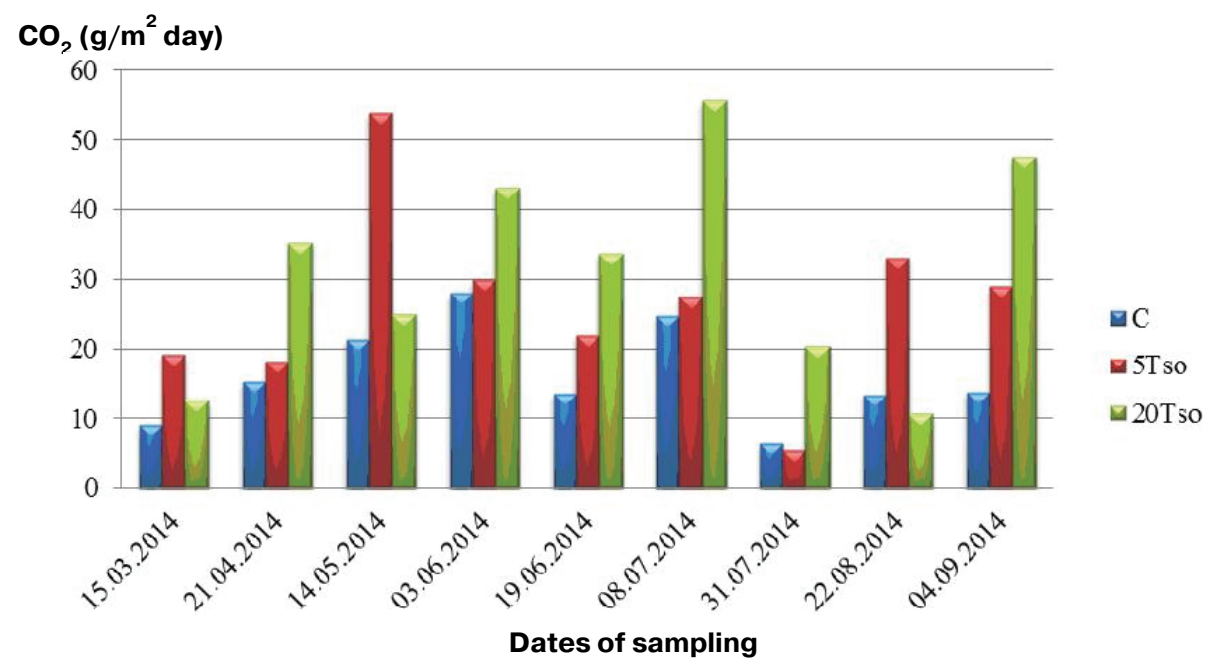

Figure 4. $\mathrm{CO}_{2}$ fluxes from control (C), $5 \mathrm{~cm}$ turf-soil (5Tso) and $20 \mathrm{~cm}$ turf-soil (20 Tso) for the period March $15-$ September 42014

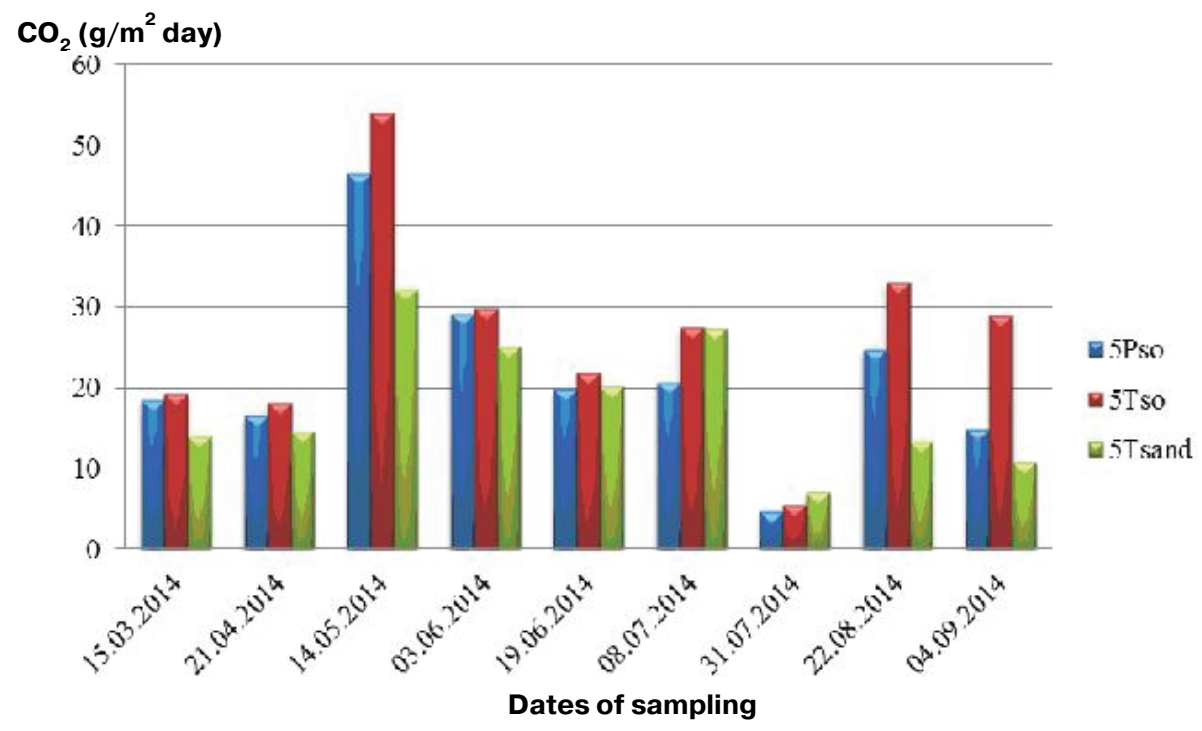

Figure 5. Seasonal dynamics of $\mathrm{CO}_{2}$ fluxes from three construction with the same depth of organic layer $(5 \mathrm{~cm})$, but different substrates: peat-soil (5Pso), Tso (5Tso) and turf-sand (5Tsa)

The experiment has demonstrated the evaluation of carbon dioxide from different artificial soil construction with different soil sample for lawn ecosystem and as a result we have got to understand how the carbon dioxide from the soil is related to the moisture and the temperature. This outcome is necessary to estimate the total losses of organic carbon from urban soil constructions from the intensive emission. soil management practices like increasing soil organic carbon content. Obtained results show that there is dependence between $\mathrm{CO}_{2}$ emission and type of soil. The $\mathrm{CO}_{2}$ emission can be reduced by sequestering $\mathrm{C}$ in the soil for those that lost high amount of organic carbon due to mineralization of organic carbon. 


\section{CONCLUSIONS}

As a result of the research data of $\mathrm{CO}_{2}$ emissions from lawn ecosystem with a contrasting structure of soil profile has been obtained. The lowest $\mathrm{CO}_{2}$ emissions was shown for the soil constructions on the basis of peat soil mixture show, which is obviously related with the lowest average temperature and soil moisture. It is observed that artificial soil construction based on a mixture of peat soil lost less total carbon stocks due to $\mathrm{CO}_{2}$ emissions. The most optimal functioning has been shown for the peat soil sample (a mixture of soil and land capacity $5 \mathrm{~cm}$ ), for which the low rates of decorative lawns combined with a high positive value of the carbon balance. In this paper, it was clearly shown how 'fragile' can be a mixture based on turf sand, turf-soil. These soils are very unstable. The optimal designs of lawn ecosystems remain a priority for urbanized research and for applications of landscape construction.

\section{Acknowledgements}

The study was supported by the RFBR projects №NK 15-54-53117 and № NK 15-34-70003.

(C) Bhoobun Bhavish, V.I. Vasenev, R.A. Hajiaghayeva, 2016

\section{REFERENCES}

[1] Dobrovolskii, G.V. and Nikitin, E.D. Soils functions in biosphere and ecosystems Funktsii pochv $\mathrm{v}$ biosfere i ekosistemakh (Functions of Soils in the Biosphere andEcosystems), Moscow: Nauka, 1990.

[2] MEA: Millennium Ecosystem Assessment. Ecosystems and Human WellBeing: Synthesis, Washington, DC: Island Press, 2005.

[3] Blum, W.E.H. Functions of soil for society and environment, Rev. Environ. Sci. Biotechnol., 2005, vol. 4: 75-79.

[4] Lorenz, K. and Kandeler, E. Biochemical characterization of urban soil profiles from Stuttgart, Germany, Soil Biol. Biochem., 2005, vol. 37: 1373-1385.

[5] Madrid, L., Diaz Barrientos, E., and Madrid, F. Distribution of heavy metal contents of urban soils in parks of Seville, Chemosphere, 2002, vol. 49: 1301-1309.

[6] Svirejeva Hopkins, A., Schellnhuber, H.J., and Pomaz, V.L. Urbanized territories as a specific component of the global carbon cycle, Ecol. Model., 2004, vol. 173: 295-312.

[7] Vasenev, V.I., Anan'eva, N.D., and Makarov, O.A. Specific features of the ecological functioning of urban soils in Moscow and Moscow oblast, Euras. Soil Sci., 2012, no. 2: 194-205.

[8] Pouyat, R.V., Yesilonis, I.D., and Nowak, D.J.Carbonstorage by urban soils in the United States, J. Environ. Quality, 2006, vol. 35: 566-575.

[9] Stroganova, M.N., Myagkova, A.D., and Prokof'eva, T.V. The role of soils in urban ecosystems, Eurasian Soil Sci., 1997, no. 1: 82-86.

[10] Imhoff, M.L., Bounoua, L., DeFries, R., et al.The consequences of urban land transformation on net primary productivity in the united states, Rem. Sens. Environ., 2004, vol. 89: 434 443.

[11] Alberty, C.A., H.M. Pellett, and D.H. Taylor. 1984. Characterization of soil compaction at construction sites and woody plant response. f. Environ. Hort. 2(2): 48-53.

[12] Blume, H.P. 1986. Characteristics of urban soils. In Man and the Biosphere, edited by the German National Committee. International scientific workshop on soils and soil zoology in urban systems as a basis for management and of green/open spaces. Berlin: UNESCO: $23-46$. 
[13] Craul, P.J. 1985a. Urban soils. METRIA 5: 45-61.

[14] Craul, P.J. and C.J. Klein. 1980. Characterization of streetside soils of Syracuse, New York. METRIA 3: 88-101.

[15] Gilman, E.F., I.A. Leone, and F.B. Flower. 1987. Effect of soil compaction and oxygen content on vertical and horizontal root distribution. Environ. Hort. 5(1): 33-36.

[16] Hillel, D. 1980. Fundamentals of Soil Physics. NewYork: Wiley.

[17] Zemlyanitsky, L.T. 1963. Characteristics of the soils in the cities. Sov. SoilSci. (5): 468 - 475.

[18] de Jong, E., Schappeart, H.J.V. and Macdonald, K.B., Can. J. Soil Sci., 1974, 54, 299- 307.

[19] Bunt, J.S. and Rovira, A.D. Nature, 1954, 173, 1242.

[20] Macfadyen, A. in Soil Organisms (eds Docksen, J. and Van der Drift, J.), North Holland, Amsterdam, 1963:3-16.

[21] Macfadyen, A. in Methods of Study in Soil Ecology (ed. Phillipson, J.), IBP/UNESCO Symp., Paris, 1970:167-172.

[22] Reichle, D.E., McBrayer, J.F. and Ausmus, B.S. in Progress in Soil Zoology (ed. Vanek, J.), Academic Publishing, Czechoslovakia, 1975:283-292.

[23] Edward, N.T., Proc. Soil Sci. Soc. Am. J., 1975, 39: 361-365.

[24] Wiant, H.V. Jr., J. For., 1967, 65: 489—490.

[25] Bouma, J., Kai, L.N., David, M.E. and Jonathan, P.L. Plant Soil, 1997, 195: 221—232.

[26] Johnson, D., Geisinger, D., Walker, R., Newman, J., Vose, J., Elliot, K. and Ball, T. Plant Soil, 1994, 165:129-138.

[27] Orchard Valerie, A. and Cook, F.J., Soil Biol. Biochem., 1983, 15: 447—453.

[28] Bandaranayake W., Y.L. Qian, W.J Parton, D.S Ojima. and R.F. Follett. 2003. Estimation of Soil Organic Carbon Changes in Turfgrass Systems Using the CENTURY Model. Agronomy Journal 95: 558-563.

\title{
АНАЛИЗ ЭМИССИИ УГЛЕКИСЛОГО ГАЗА В ГАЗОННЫХ ЭКОСИСТЕМАХ В УСЛОВИЯХ КОНТРАСТНЫХ ПОЧВЕННЫХ ПРОФИЛЕЙ
}

\author{
Бхубан Бхавиш, В.И. Васенев, \\ Р.А. Гаджиагаева \\ Российский университет дружбы народов \\ ул. Миклухо-Маклая, 8/2, Москва, Россия, 117198
}

\begin{abstract}
Изменение землепользования является одним из главных факторов, способствующих изменению климата. Урбанизация является землепользованием, которое связано с быстрым ростом городских территорий, вследствие чего происходят необратимые изменения особенностей почвы и ее функционирования. Эмиссия парниковых газов (преимущественно эмиссия $\mathrm{CO}_{2}$ ) и депонирование углерода являются одними из важнейших функций почв. Экологические риски увеличивающейся эмиссии $\mathrm{CO}_{2}$ в городских почвах определяются различными факторами антропогенного воздействия. Целью данной статьи является анализ воздействия различных почвенных конструкций на эмиссию $\mathrm{CO}_{2}$ в газонных экосистемах. Объект исследования расположен в северном административном
\end{abstract}


округе (САО) г. Москвы и включает в себя почвенные конструкции с различными по происхождению (торф, торфяно-песчаная смесь и почво-песчаная смесь) и мощности $(5,10,20$ см) органическими горизонтами. По полученным данным, средняя эмиссия $\mathrm{CO}_{2}$ в варианте с торфяным органогенным горизонтом мощностью $20 \mathrm{~cm}$ составила $22,00 \mathrm{r} / \mathrm{m}^{2}$ в день, в то время как в варианте с торфяно-песчаной смесью мощностью 10 см эмиссия составила 16,15 г/м², а торфяной почвы мощностью 5 см - 19,23 г/м² в день. Следовательно, наблюдается зависимость эмиссии углекислого газа от таких показателей, как генезис органического вещества почвы и мощность органогенного горизонта. Также в течение 9 месяцев наблюдений была выявлена зависимость эмиссии углекислого газа от климатических условий.

Ключевые слова: эмиссия $\mathrm{CO}_{2}$, урбанизация, экологические риски, парниковые газы, почвенное дыхание 